\title{
A Pilot Study on Stress and Coping Strategies in Infertile Women under in Vitro Fertilization Treatment
}

\author{
Tüp Bebek Tedavisi Gören İnfertil Bireylerde Stres ve Stresle Başa Çıkma \\ Yaklaşımları Üzerine Pilot Bir Çalışma
}

Can Karpat ${ }^{1}$, Habib Erensoy ${ }^{2}$

\begin{abstract}
Aim: In recent years, the prevalence of infertility has increased. Diagnostic and therapeutic processes affect these infertile women physically and psychologically, and these women may have trouble for controlling their stress. In this study, coping strategy styles of the individuals undergoing infertility treatment were examined. Material and Methods: The sample of thestudyconsists of 63 infertilewomen. Sociodemographic Information Form, Infertility Stress Scale and Infertility Stress and Coping Strategy Scale were applied to the sample of ourstudy. Results: All participants were women between 18-49 years of age. When the correlations between subscale and total scale scores of the Coping Strategy Scale of the participants were examined; there was a positive, weak-moderate, statistically significant correlation between the subscale scores of "active-confronting coping" and " meaning-based coping. When the correlations between the subscale scores of the Fertility Problem Stress Scale and the Coping Strategy Scale were examined, there was only a weak-moderate statistically significant correlation between the stress in the personal domain with active avoidance coping and meaning-based coping subscale scores. Conclusion:There is an increase in stress levels and stress coping strategies in infertile women. Based on these findings, it can be suggested that female individuals diagnosed with infertility sould receive psychological support during the treatment process.
\end{abstract}

KeyWords: Infertility treatment; in vitro fertilization; stress coping strategies

\section{ÖZET}

Amaç: Son yıllarda infertilite sorunu yaşayan bireylerin sayısında bir artışa rastlanmıştır. Tanı ve tedavi süreçlerinin bireyleri gerek fiziksel gerekse psikolojik olarak yıprattığı bilinmektedir. Yaşanan bu durum karşısında bireyler streslerini kontrol altına almakta güçlük çekebilmektedirler. Bu çalışmada tüp bebek tedavisi gören infertil hastalarin stres ile başa çıkma yöntemleri incelenecektir. Gereç ve Yöntemler: Çalışmanın örneklemi 63 infertil kadından oluşmaktadır. Katılımcılara Sosyodemografik Bilgi Formu, İnfertilite Stres Ölçeği ve İnfertilite Stresi ile Başa Çıkma Ölçeği uygulanmıştır. Bu çalışma Kasım2019- Ocak 2020 tarihleri arasında yapılmıştır. Bulgular: Çalışmamıza katılan kişilerin tamamı, 18-49 yaş arasındaki kadınlardan oluşmaktadır. Katılımcıların "İnfertilite Stresi ile Başa Çıkma Ölçeği" alt boyut ve toplam ölçek puanları arasındaki korelasyonlar incelendiğinde; alt boyut puanları arasında sadece "aktif mücadele etme" ve "anlam bulma temelli" alt boyut puanları arasında pozitif yönde, zayıf-orta düzeyde, istatistiksel olarak anlamlı korelasyon bulunmuştur. Katılımcıların "İnfertilite Stresi Ölçeği” ve "İnfertilite Stresi ile Başa Çıkma Ölçeği” alt boyut puanları arasındaki korelasyonlar incelendiğinde sadece "kişisel alanda stres" ile "aktif yok sayma" ve "anlam bulma temelli" alt boyut puanları arasında zayıf-orta düzeyde, istatistiksel olarak anlamlı korelasyonlar bulunmuştur. Sonuç: Tüp bebek tedavisi gören infertil kadınların stres düzeyleri ve aynı şekilde stres ile başa çıkma yöntemleri de artış eğilimi göstermektedir. Bu bağlamda infertilite teşhisi almış kadın bireylerin tedavi sürecinde psikolojik destek almaları önerilebilir.

Anahtar kelimeler: İnfertilite tedavisi; tüp bebek; stres ile başa çıkma yöntemleri

Received / Geliş tarihi: 14.05.2020, Accepted / Kabul tarihi: 10.07.2020

${ }^{1}$ Klinik Psikolog, Üsküdar Üniversitesi NP Beyin Hastanesi Psikiyatri Birimi

2 Öğretim Üyesi Doktor, Psikiyatri uzmanı, Üsküdar Üniversitesi Tıp Fakültesi Psikiyatri Anabilim Dalı

*Address for Correspondence / Yazışma Adresi: Habib Erensoy, NP Etiler Tıp Merkezi, Nispetiye Caddesi No: 19 Levent Beşiktaş İstanbul TÜRKIYE, E-mail: habiberensoy@yahoo.com

Karpat C, Erensoy H. Tüp Bebek Tedavisi Gören İnfertil Bireylerde Stres ve Stresle Başa Çıkma Yaklaşımları Üzerine Pilot Bir Çalışma. TJFMPC, 2020;14(3): 461-467.

DOI: $10.21763 /$ tjfmpc. 737420 


\section{Gİiș}

Dünya Sağlık Örgütü’ne (DSÖ) göre, infertilitenin güncel tanımı "enaz 12 ay süre boyunca korunmasız ilişkiye girilmesi durumunda gebe kalınmaması" olarak belirlenmiştir. ${ }^{[1,}{ }^{2]}$ İnfertilite sorununa sahip olmak, bireyleri gerek fiziksel gerekse psikolojik olarak etkilemekte, bireysel ve sosyal hayatlarında sorunlar yaratmaktadır. İnfertilite sorunu yaşayan bireyler çocuk sahibi olabilmek için belirli tedavi yöntemlerine başvururlar. Bunlardan son dönemlerde en bilineni ve en yaygın kullanılanı In Vitro Fertilization (IVF) yöntemidir. İnfertilite, fiziksel, psikolojik, sosyal, duygusal ve maddi etkileri olan bir durumdur. İnferfilite sorunu yaşayan çiftler, yaşadıkları sorunun özel olması ve karşılaştıkları sosyal baskılar nedeniyle deneyimledikleri problemi saklama gereksinimi duymaktadırlar. ${ }^{[3]}$

İnfertilite tanısı almış olan bireylerde gözlemlenen birçok etki bulunmaktadır. Bu etkiler tanı almış kişilerin hayatlarını olumsuz yönde etkilemektedir. Bu faktörlerden en önemlisi kişilerin içinde bulundukları duruma verdikleri psikolojik ve psikososyal reaksiyonlardır. ${ }^{[4-12]}$

Bir Akdeniz ülkesi olan aynı zamanda komşu ülkemiz Yunanistan'da yapılan bir araştırmada kadınların, erkeklere nazaran sosyal uyum konusunda daha fazla problemle karşılaştıkları gözlemlenmiştir. $\mathrm{Bu}$ sorunlar genellikle evlilik alanında gözlemlenmiş olsa dahi, cinsel sorunlara bakıldığında da vakaların yaklaşık \%50'sinde cinsel problemlerin varlığ 1 görülmüştür. ${ }^{[13]}$

İnfertilite stresi tek başına bile başa çıkılması zor bir durumdur, bu duruma tanı ve tedavi süreçleri de dahil olduğunda bireyler başa çıkmada zorluk çekerler. İnfertilite teşhisi alan kadın ve erkeklerde başa çıkma yöntemlerinin kullanılması tedavi sürecinin gidişatını da etkilemektedir. $\mathrm{Bu}$ sebeple stres yaşayan infertil çiftler başa çıkma yöntemlerini kullanarak olumsuz olabilecek sonuçları en aza indirmeli veya eğer başarabiliyorlarsa tamamen ortadan kaldırmalıdırlar. ${ }^{[12,14-16]}$

İnfertilite stresi üzerine yapılan çalışmalarda farklı başa çıkma yöntemlerine rastlanmıştır. Peterson ve ark. 2006 yılında yaptıkları çalışmada ${ }^{[15]}$ infertilite stresi ile başa çıkma yöntemlerini "meydan okuyarak başa çıkma", "uzaklaştırma", "kendini kontrol etme", “" sosyal destek arama", "sorumluluğu kabul etme", "kaçış/uzak durma", "planlı problem çözme" ve "pozitif yeniden değerlendirme" olmak üzere sekiz alt boyutta, Lechner ve ark. 2007 y1lındaki çalışmalarında [17] "aktif" ve "pasif olmak üzere iki alt boyutta, Bayley ve ark. 2009 yilındaki çalışmalarında ${ }^{[18]}$ "kendini suçlama/kaçınma", "emosyonel destek arama" ve "bilişsel yeniden yapılandırma" olarak üç alt boyutta değerlendirmişlerdir ${ }^{16}$. $\mathrm{Bu}$ çalışmanın amacı, infertilite tanısı almış kadın bireylerdeki stres seviyelerini ve bu stres ile başa çıkma yöntemlerini incelemektir.

\section{GEREÇ VE YÖNTEMLER}

Bu pilot çalışmanın örneklemini İstanbul ilinde bir İn Vitro Fertilizasyon polikliniğine başvurmuş 63 infertil kadın birey oluşturmaktadır. Çalışma Kasım 2019-Ocak 2020 tarihleri arasında yapılmıştır.

\section{Veri Toplama Araçları}

Araştırmada nicel araştırma yöntemlerinden biri olarak anket uygulama yöntemi kullanılmıştır. Veri toplamak aracıyla katılımcılara Bilgilendirilmiş Onam Formu, Sosyodemografik Bilgi Formu, Schmidt tarafından geliştirilmiş olan ve Yılmaz ve Oskay tarafından Türkçe geçerlilik-güvenirliliği yapılmış olan İnfertilite Stres Ölçeği (İSÖ) uygulanmıştır. ${ }^{[19,20]}$

Çalışmaya dahil edilme kriterleri 1849yaşarası in vitro fertilizasyon adayı kadınlar, Dışlama kriterleri ise araştırmaya katılımı Kabul etmeyen ve önceden psikiyatrik tanı alan kadınlar olarak belirlenmiştir.

Araştırmanın dahil olma ve dışlama kriterlerini dikkate alarak 63 anket toplanmıştır.

Sosyodemografik Bilgi Formu: Sosyodemografik Bilgi Formu katılımcıların; cinsiyetleri, yaşları, eğitim durumları, medeni durumları, mesleki durumları, ekonomik durumları, evlilik süreleri, infertilite tedavi süreleri, infertilitenin kimden kaynaklı olduğu, daha önce IVF uygulaması yapılıp yapılmadığ 1 , yapıldı ise gebe kalma durumunu vb. gibi bilgilere ulaşmak amaçlanmaktadır.

İnfertilite Stresi Ölçeği (The COMPI Fertility Problem Stress Scales): İnfertil çiftlerin yaşadıkları stresi değerlendirmek için uygulanacak olan bu ölçek Schmidt tarafından geliştirilmiştir. ${ }^{[19]}$ İnfertilite Stresi Ölçeği (The COMPI Fertility Problem Stress Scales) üç alt boyuttan oluşan, hem kadınlara hem erkeklere uygulanabilen 14 maddelik bir ölçektir. Bu çalışmada ölçek ve alt boyutların Cronbach alfa katsayıları kişisel alanda Stres için 0.781, evlilik alanında stres için 0.851 ,sosyal alanda stres için 0.769 olarak bulunmuştur.

İnfertilite Stresi ile Başa Çıkma Ölçeği (The COMPI Coping Strategy Scales): İnfertil çiftlerin yaşadıkları stresle başa çıkmalarını değerlendirmek için uygulanacak olan bu ölçek Schmidt tarafından 
geliştirilmiştir. Schmidt ölçeğin geliştirilmesinde üç kaynaktan yararlanmıştır. Bunlar; Schmidt'in infertilite ile ilgili yaptı̆̆ niteliksel görüşme sonuçlarından beş madde ${ }^{[19]}$, Lazarus ve Folkman'ın ${ }^{[21]}$ geliştirmiş olduğu Başa Çıkma Yolları Anketinden (Ways of Coping Questionnaire) dokuz madde ve Folkman'ın ${ }^{[22]}$ geliştirmiş olduğu ve Şahin ve Durak tarafından Türkçe geçerlilikgüvenirliliği yapılmış olan ${ }^{[23]}$ Başa Çıkma Yolları Anketinin revize edilmesi ile elde edilen şeklinden alınan beş maddedir. İnfertilite Stresi ile Başa Çıkma Ölçeği (The COMPI Coping Strategy Scales) dört alt boyuttan oluşan, hem kadınlara hem erkeklere uygulanabilen 19 maddelik bir ölçektir. Bu çalışmada ölçek ve alt boyutların Cronbach alfa katsayıları aktif yok sayma için 0,690, aktif mücadele etme için 0,688,pasif yok sayma için 0,663 ve anlam bulma temelli için 0,715 olarak bulunmuştur.

\section{Araştırmanın Etik Yönü}

Araştırma üniversitemizin girişimsel olmayan etik kurulunun 61351342-/2019-473 say1l ve 24.10.2019 tarihli izniyle yapılmıştır. Hastalardan yazılı onam formu alınarak araştırmaya başlanmıştır.

\section{İstatistiksel Analiz}

İstatistik analizler IBM SPSS versiyon 21.0 (IBM Corp. Released 2012. Armonk, NY, USA) paket program ile yapıldı. Tanımlayıcı istatistikler ortalama, standart sapma, ortanca, en küçük, en büyük, frekans, yüzde olarak verildi. Sürekli değişkenlerin normal dağılıma uygunluğu Kolmogorov Smirnov testi ile değerlendirildi. Sürekli değişkenlere ait gruplararası karşılaştırmalar Mann Whitney U testi ve Kruskal Wallis testi ile gerçekleştirildi. Kruskal Wallis testi ile yapılan karşılaştırmalarda gruplar arasında istatistiksel anlamlı farklılık bulunduğunda farkın hangi gruplardan kaynaklandığını belirlemek için posthoc Bonferroni düzeltmeli Mann Whitney U testi kullanıldı. Değişkenler arasındaki doğrusal ilişki Spearman korelasyon testi ile değerlendirildi. İstatistiksel önemlilik için $\mathrm{p}<0,05$ değeri kabul edildi.

\section{BULGULAR}

Çalışma grubunun tamamı kadınlardan oluşmaktadır ve tüm katılımcılar 18-49 yaş ile doğurganlık yaş aralığı içerisindedir. Katılımcıların \%41,2'si üniversite ve üzeri eğitime sahiptir. Kadınların tamamına yakını evlidir $(\% 95,2)$. Çocuk sahibi olmayanlar \%85,7'lik paya sahiptir. Katılımcıların $\% 42,9$ 'u çalışmaktadır ve ekonomik durumunun iyi olduğunu bildirenler tüm grubun \%17,5'ini oluşturmaktadır. Evlilik süresi 5 yıl ve üzerinde olanların payı \%71,4'tür. Ayrıntılar Tablo-1'de sunulmuştur.

\begin{tabular}{lcc}
\multicolumn{3}{l}{ Tablo-1 Katılımcıların Sosyodemografik Özellikleri (n=63) } \\
\hline Özellik & $\mathrm{n}$ & $\%$ \\
\hline Eğitim Durumu & & \\
Okuryazar değil & 2 & 3,2 \\
İlköğretim mezunu & 18 & 28,6 \\
Lise mezunu & 17 & 27,0 \\
Üniversite mezunu & 21 & 33,3 \\
Lisansüstü & 5 & 7,9 \\
Medeni Durumu & & \\
Evli & 60 & 95,2 \\
Bekar & 2 & 3,2 \\
Boşanmış & 1 & 1,6 \\
Çocuk Sayısı & & \\
Yok & 54 & 85,7 \\
1 & 8 & 12,7 \\
2 & 1 & 1,6 \\
Çalışma Durumu & & \\
Çalışıor & 27 & 42,9 \\
Çalışmıor & 36 & 57,1 \\
Ekonomik Durumu & & \\
Ancak geçinebiliyorum & 22 & 34,9 \\
Orta derecede iyi & 30 & 47,6 \\
İyi & 11 & 17,5 \\
Evlilik Süresi & & \\
5 yıldan az & 18 & 28,6 \\
5 yll ve üzeri & 45 & 71,4 \\
\hline & & \\
& &
\end{tabular}

Kadınların \%34,9’u 5 y1l ve üzerinde infertilite tedavi süresine sahiptir. İnfertilite sorunu kadın kaynaklı olan grup \%79,4'tür. Kadınların yarısından fazlasina $(\% 50,8)$ IVF uygulaması gerçekleştirilmiştir. IVF uygulaması yapılan kadınlarda gebelik oluşanların payı \%18,8'dir. Gebelik gerçekleşen bu 6 kadından biri doğum yapmiştır.

Katılımcıların "İnfertilite Stresi Ölçeği” toplam ve alt boyutlarına ait tanımlayıcı istatistikleri Tablo-2'te verilmiştir.

Katılımcıların eğitim durumuna, ekonomik duruma, çalışma durumuna, çocuk sayısına, evlilik süresine, tedavi süresine, infertilite sorununun kimden kaynaklandığına, daha önce IVF uygulaması yapılması durumuna göre "İnfertilite Stresi Ölçeği" alt boyut ve toplam puanları karşılaştırıldığında, gruplar arasında istatistiksel olarak anlamlı farklılık saptanmamıştır $(\mathrm{p}>0,05)$.

Katılımcılarda eğitim durumlarına göre "İnfertilite Stresi ile Başa Çıkma Ölçeğì" alt boyut ve toplam puanları karşılaştırıldığında, "aktif mücadele etme " alt boyut puanı ilköğretim ve altı grupta üniversite ve üzeri gruba göre istatistiksel olarak anlamlı düşüktür. "Pasif yok sayma" alt boyut puanı ise ilköğretim ve altı grupta üniversite ve üzeri gruba göre istatistiksel olarak anlamlı yüksek 
bulunmuştur $(\mathrm{p}<0,05)$. Diğer karşıllaştırmalarda gruplar arasında istatistiksel olarak anlamlı farklılık bulunmamıştır $(\mathrm{p}>0.05)$.

Tablo-2Katılımcıların İnfertilite Stresi Ölçek Puanlarına Ait Tanımlayıcı İstatistikleri (n=63) SS= StandartSapma

\begin{tabular}{llcl}
\hline Alt Boyut/Ölçek Puanı & Ortalama \pm SS & Ortanca & En Küçük-En Büyük \\
\hline Kişisel alanda stres & $11,4 \pm 4,7$ & 12 & $0-20$ \\
Evlilik alanında stres & $4,4 \pm 4,2$ & 3 & $0-14$ \\
Sosyal alanda stres & $3,0 \pm 3,0$ & 2 & $0-9$ \\
Toplam & $18,8 \pm 10,2$ & 19 & $0-43$ \\
\hline
\end{tabular}

Tablo- 3Katılımcıların İnfertilite Stresi ile Başa Çıkma Ölçeği Alt Boyutları ve Toplam Puanları Arasındaki Korelasyonlar (n=63)

\begin{tabular}{lccccc}
\hline Alt Boyut/Ölçek Puanı & $\begin{array}{l}\text { Aktif Yok } \\
\text { Sayma }\end{array}$ & Aktif Mücadele Etme & $\begin{array}{l}\text { Pasif Yok } \\
\text { Sayma }\end{array}$ & $\begin{array}{l}\text { Anlam Bulma } \\
\text { Temelli }\end{array}$ & Toplam \\
\hline Aktif Yok Sayma & & 0,030 & 0,175 & 0,173 & $\mathbf{0 , 5 1 2 *}$ \\
Aktif Mücadele Etme & & 0,111 & $\mathbf{0 , 4 5 0 *}$ & $\mathbf{0 , 7 0 4 *}$ \\
Pasif Yok Sayma & & & 0,222 & $\mathbf{0 , 4 8 8 *}$ \\
Anlam Bulma Temelli & & & $\mathbf{0 , 7 2 6 *}$ \\
\hline
\end{tabular}

$\mathrm{r}_{\mathrm{s}}=$ Spearman korelasyon katsayıs $\quad * \mathrm{p}<0,001$

Tablo-4 Katılımcıların İnfertilite Stresi Ölçeği ve İnfertilite Stresi ile Başa Çıkma Ölçeği Alt Boyutları ve Toplam Puanları Arasındaki Korelasyonlar $(\mathrm{n}=63)$

\begin{tabular}{|c|c|c|c|c|}
\hline Alt Boyut/Ölçek Puanı & $\begin{array}{c}\text { Aktif Yok } \\
\text { Sayma }\end{array}$ & $\begin{array}{c}\text { Aktif Mücadele } \\
\text { Etme }\end{array}$ & $\begin{array}{l}\text { Pasif Yok } \\
\text { Sayma }\end{array}$ & $\begin{array}{l}\text { Anlam Bulma } \\
\text { Temelli }\end{array}$ \\
\hline Kişisel Alanda Stres & $0,352 * *$ & $-0,036$ & 0,027 & $-0,314 *$ \\
\hline Evlilik Alanında Stres & 0,190 & $-0,025$ & $-0,074$ & $-0,158$ \\
\hline Sosyal Alanda Stres & 0,124 & $-0,104$ & $-0,065$ & $-0,187$ \\
\hline
\end{tabular}

Tablo-5 Katılımcıların İnfertilite Stresi ve İnfertilite Stresi ile Başa Çıkma Ölçek Puanları Arasındaki Korelasyon (n=63)

\begin{tabular}{llc}
\hline Toplam Puan & \multicolumn{2}{l}{ İnfertilite Stresi ile Başa Çıkma Ölçeği } \\
\hline İnfertilite Stresi Ölçeği & $\mathrm{r}_{\mathrm{s}}$ & $\mathrm{p}$ \\
\hline
\end{tabular}

$\mathrm{r}_{\mathrm{s}}=$ Spearman korelasyon katsay1si

Katılımcıların çalıșma durumlarına göre "İnfertilite Stresi ile Başa Çıkma Ölçeği”" alt boyut ve toplam puanları karşılaştırıldığında; "pasif yok sayma" alt boyut puanı çalışmayan grupta istatistiksel olarak anlamlı yüksek bulunmuştur $(p<0,05)$. Diğer alt boyut ve toplam puanlarda gruplar arasında istatistiksel olarak anlamlı farklılık bulunmamıştır $(\mathrm{p}>0,05)$.

Katılımcıların çocuk sayılarına göre "İnfertilite Stresi ile Başa Çıkma Ölçeği” alt boyut ve toplam puanları karşılaştırıldığında, "çocuğu olmayan" grupta "anlam bulma temelli" alt boyut puanı çocuğu olan gruptan istatistiksel olarak anlamlı yüksek bulunmuştur $(\mathrm{p}<0,05)$. Diğer alt boyut ve toplam puan karşılaştırmalarında gruplar arasında istatistiksel olarak anlamlı farklılık saptanmamıştır $(\mathrm{p}>0,05)$.

Katılımcıların ekonomik durumlarına göre "İnfertilite Stresi ile Başa Çıkma Ölçeği” alt boyut ve toplam puan karşılaştırıldığında, "ancak geçinebiliyorum" yanıtını veren grupta "iyi”" yanıtını veren gruba göre "pasif yok sayma" alt boyut puanı istatistiksel olarak anlamlı yüksek bulunmuştur $(p<0,05)$. Diğer alt boyut ve toplam puan karşılaştırmalarında gruplar arasında istatistiksel olarak anlamlı farklılık bulunmamıştır $(\mathrm{p}>0,05)$.

Katılımcıların evlilik süresine göre “İnfertilite Stresi ile Başa Çıkma Ölçeğii” alt boyut 
ve toplam puanları karşılaştırıldığında gruplar arasında istatistiksel olarak anlamlı farklılık bulunmamıştır $(\mathrm{p}>0,05)$.

Katılımcıların infertilite tedavi süresine göre "İnfertilite Stresi ile Başa Çıkma Ölçeği” alt boyut ve toplam puan karşılaştırıldığında, tedavi süresi 5 y1l ve üzeri olan grupta "aktif yok sayma" alt boyut puanı istatistiksel olarak anlamlı yüksektir $(p<0,05)$. Diğer alt boyut ve toplam puan karşılaştırmalarında gruplar arasında istatistiksel olarak anlamlı farklılık bulunmamıştır.

Katılımcılarda infertilite sorununun kimden kaynaklandığında göre "İnfertilite Stresi ile Başa Çıkma Ölçeği” alt boyut ve toplam puan karşılaştırıldığında, tüm alt boyut ve toplam puanlarda kadın kaynaklı grupta daha düşük puanlar bulunmakla birlikte gruplar arasında istatistiksel olarak anlamlı farklılık saptanmamıştır ( $p>0,05)$.

Katılımcilarda daha önce IVF uygulaması yapılması durumuna göre "İnfertilite Stresi ile Başa Çıkma Ölçeği" alt boyut ve toplam puan karşılaştırıldığında, tüm alt boyut ve toplam puanlarda gruplar arasında istatistiksel olarak anlamlı farklılık saptanmamıştır $(\mathrm{p}>0,05)$.

Daha önce IVF uygulaması yapılmış kadınlar arasında gebe kalma durumuna göre "İnfertilite Stresi ile Başa Çıkma Ölçeği”" alt boyut ve toplam puan karşılaştırıldığında, gebe kalmış kadınlarda "aktif yok sayma" alt boyut puanı istatistiksel olarak anlamlı yüksektir $(\mathrm{p}<0,05)$. Diğer karşılaştırmalarda gruplar arasında istatistiksel olarak anlamlı farklılık saptanmamıştır ( $\mathrm{p}>0,05)$.

Katılımcıların "İnfertilite Stresi Ölçeği” alt boyut ve toplam ölçek puanları arasındaki korelasyonlar incelendiğinde; tüm alt boyut puanları arasında pozitif yönde, orta-iyi düzeyde, istatistiksel olarak anlamlı korelasyonlar bulunmuştur $(\mathrm{p}<0,05)$. Tüm alt boyut puanları ile toplam ölçek puanı arasında ise pozitif yönde, iyi düzeyde, istatistiksel olarak anlamlı korelasyonlar saptanmıştır $(\mathrm{p}<0,05)$.

Katılımcıların "İnfertilite Stresi ile Başa Çıkma Ölçeği”" alt boyut ve toplam ölçek puanları arasındaki korelasyonlar incelendiğinde; alt boyut puanları arasında sadece "aktif mücadele etme" ve "anlam bulma temelli" alt boyut puanları arasında pozitif yönde, zayıf-orta düzeyde, istatistiksel olarak anlamlı korelasyon bulunmuştur $(p<0,05)$. Diğer alt boyut puanları arasında istatistiksel olarak anlamlı korelasyon saptanmamıştır ( $p>0,05)$. Tüm alt boyut puanları ile toplam ölçek puanı arasında ise pozitif yönde, istatistiksel olarak anlamlı korelasyonlar mevcuttur $(p<0,05)$. Toplam ölçek puanı "pasif yok sayma" alt boyut puanı ile zayıf-orta, "aktif yok sayma" alt boyut puanı ile orta-iyi, "aktif mücadele etme" ve "anlam bulma temelli" alt boyut puanları ile ise iyi düzeyde koreledir. Ayrıntılar Tablo-3'de sunulmuştur.

Katılımcıların "İnfertilite Stresi Ölçeği” ve “İnfertilite Stresi ile Başa Çıkma Ölçeğì” alt boyut puanları arasındaki korelasyonlar incelendiğinde sadece "kişisel alanda stres" ile "aktif yok sayma" ve "anlam bulma temelli" alt boyut puanları arasında zayıf-orta düzeyde, istatistiksel olarak anlamlı korelasyonlar bulunmuştur $(p<0,05)$. "Aktif yok sayma" alt boyutu puanı ile pozitif yönde, "anlam bulma temelli" alt boyut puanı ile ise negatif yönde korelasyon mevcuttur. Diğer alt boyut puanları arasında ise istatistiksel olarak anlamlı korelasyon saptanmamıştır $(p>0,05)$. Ayrıntılar Tablo-4'te sunulmuştur.

Katılımcıların "İnfertilite Stresi Ölçeği” ve “İnfertilite Stresi ile Başa Çıkma Ölçeği” toplam puanları arasındaki korelasyon incelendiğinde ise negatif yönde, zayıf, istatistiksel olarak anlamlı olmayan korelasyon bulunmuştur $(p>0,05)$. Ayrıntılar Tablo-5'de sunulmuştur.

\section{TARTIŞMA}

İnfertilite, bireylerin psikolojik ve fiziksel sağlığını etkilemektedir. $\mathrm{Bu}$ bölümde çalışmaya katılan infertil kadın bireylerin İSÖ ve İSBÇÖ alt boyutlarına dair bulguları tartışılmıştır.

Elde ettiğimiz sonuçlara göre "İnfertilite Stresi Ölçeği” alt boyut ve toplam ölçek puanları arasındaki korelasyonlarda tüm alt boyut puanları arasında pozitif yönde, orta-iyi düzeyde, istatistiksel olarak anlamlı korelasyonlar bulunmuştur. Tüm alt boyut puanları ile toplam ölçek puanı arasında ise pozitif yönde, iyi düzeyde, istatistiksel olarak anlamlı korelasyonlar saptanmıştır. Çalışmamızda olduğu gibi Peterson ve ark. ve Yılmaz da İSÖ tüm alt boyut puanları arasında pozitif bir ilișki saptamışlardır. ${ }^{[15,16]} \mathrm{Bu}$ sonuçlar bize infertilite stresinin tanı almış bireylerin hayatlarını etkilediğini göstermiş ve çalışmamızı desteklemiş̧ir.

Aynı şekilde "İnfertilite Stresi ile Başa Çıkma Ölçeği" alt boyut ve toplam ölçek puanları arasındaki korelasyonlarda alt boyut puanları arasında sadece "aktif mücadele etme" ve "anlam bulma temelli" alt boyut puanları arasında pozitif yönde, zayıf-orta düzeyde, istatistiksel olarak anlamlı korelasyon bulunmuştur. Diğer alt boyut puanları arasında istatistiksel olarak anlamlı korelasyon saptanmamıştır. Tüm alt boyut puanları ile toplam ölçek puanı arasında ise pozitif yönde, istatistiksel olarak anlamlı korelasyonlar mevcuttur. Toplam ölçek puanı "pasif yok sayma" alt boyut puanı ile zayıf-orta, "aktif yok sayma" alt boyut puanı ile orta-iyi, "aktif mücadele etme" ve "anlam 
bulma temelli" alt boyut puanları ile ise iyi düzeyde koreledir. Tıpkı İSÖ'de olduğu gibi, İSBÇÖ tüm alt boyut puanları arasındaki pozitif yönlü ilişki bazı çalışmalarında da bulunmuștur. ${ }^{[16,24]} \mathrm{Bu}$ durum hayatlarını etkileyen infertilite stresi için farklı baş etme metotları kullanma ihtiyacı hissettiklerini göstermekte ve çalışmamızı desteklemektedir.

Ancak, iki ölçek toplam puanları arasındaki korelasyon incelendiğinde ise negatif yönde, zayıf, istatistiksel olarak anlamlı olmayan korelasyon bulunmuştur. Bu negatif yönde, zayıf ve istatistiksel olarak anlamlı olmayan korelasyonun nedeni yaptığımız çalışmanın örneklem sayısının az olmasidir.

Schmidt, Christensen ve ark.'ının 2005 ve 2006 yılında geliştirdikleri bir ölçek olan İSBÇÖ ise içerisinde 19 soru ile birlikte 4 alt boyut barındırmaktadır. ${ }^{[19,25]}$ Bunlardan ilki "aktif yok sayma" alt boyutudur. Çalışmamızda bu alt boyut için $8,9 \pm 3,1$ gibi ortalama bir değer bulunmuştur. Literatür incelendiğinde çalışmamız Holter ve ark.nın 2006 yılında gerçekleştirdikleri çalışmanın sonuçları ile uyum içerisindedir ${ }^{26}$.

İkinci alt boyut olan "aktif mücadele etme" alt boyutunda elde edilen değer 16,1 $\pm 3,8$ bulunmuştur. Literatür incelendiğinde bu davranışın erkek bireylere nazaran kadınlar tarafindan daha sik kullanıldığı sonucuna ulaşılmıştır. Elde ettiğimiz yüksek ortalama ve yapılmış diğer çalışmaların sonuçları da çalışmamızı desteklemektedir. ${ }^{[16]}$

Üçüncü alt boyut "pasif yok sama" alt boyutudur. Çalışmamızda elde ettiğimiz ortalama değer 8,9 $\pm 2,6$ 'dır. Bu alt boyutta skorun düşük olması katılımcıların özelliklerine ve hayata bakış açılarının literatürdeki diğer çalışmalardan farklı olmasına bağlanabilir. Bu değer diğer bir alt boyut olan "aktif yok sayma" ile aynı ortalamaya sahiptir.

Son alt boyut ise "anlam bulma temelli" alt boyutudur. Burada elde ettiğimiz sonuç ise 13,7 $\pm 3,4$ ile ikinci sıradadır. Bu alt boyutta elde ettiğimiz sonuç literatürdeki birçok çalışmayla farklı ancak bir çalışma ile aynıdır. ${ }^{[18]}$

Eğitim seviyeleri ilköğretim ve altı olan bireylerde "aktif mücadele etme", "pasif yok sayma" ve "anlam bulma temelli" alt boyut puanları fazladır. Buna göre eğitim seviyesi düşük bireylerde bu yöntemler daha fazla kullanılmaktadır. Bu çalışma Yılmaz'ın 2012 yılında yaptığı çalışmada elde ettiği sonuçlarla uyum göstermektedir. ${ }^{[16]}$

Çalışma durumu ve ekonomik duruma göre İSBÇÖ alt boyut puanları değerlendirildiğinde; Çalışanlarda ve ekonomik durumu iyi olanlarda "aktif mücadele etme" ve "anlam bulma temelli" alt boyutları, çalışmayanlarda ve ekonomik durumu düşük olanlarda ise aynı şekilde "aktif mücadele etme" ve "anlam bulma temelli alt boyut puanlarında artış gözlemlenmiştir. Literatürde yapılan çalışmalarda bu alanlarda belirgin bir fark bulunmamıştır.

Çocuk sayılarına göre değerlendirildiğinde, çocuğu olmayanlarda ve 1 ve daha fazla çocuğu olanlarda "aktif mücadele etme" ve "anlam bulma temelli" alt boyutlarında yükseklik gözlemlenmiştir. Literatürde ise bu alanla ilgili bilgiye rastlanmamıştır.

Evlilik süreleri ele alındığında 5 yıldan az ve 5 yıl üzeri evlilik sürelerinde "aktif mücadele etme" ve "anlam bulma temelli" baş etme yöntemleri daha fazla kullanılmıştır. Literatürde yapılan tek bir araştırmada evlilik süresi ile baş etme yöntemleri arasındaki ilişki incelenmiş ve onda da fark bulunmamıştır. ${ }^{[16]}$

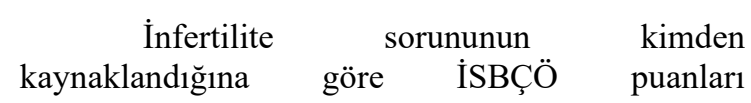
karşılaştırıldığında; kadın kaynaklı ve nedeni belli olmayan infertilite alanlarında "aktif mücadele etme" ve "anlam bulma temelli" alt boyutları yükseklik göstermiştir. Literatürde bu sonuçlarla uyum içerisinde olan bir çalışmaya rastlanmamıştır.

Daha önce IVF uygulaması yapılması durumuna göre değerlendirildiğinde IVF yapılmış ve IVF yapılmamış olanlarda "aktif mücadele etme" ve "anlam bulma temelli" alt boyutlarında yükseklik gözlemlenmiştir.

Ve son olarak IVF uygulaması yapılanlarda gebelik durumuna göre değerlendirildiğinde gebe kalmış ve gebe kalmamış olanlarda "aktif mücadele etme" ve "anlam bulma temelli" alt boyutlarında yükseklik gözlemlenmiştir. Literatürde ise bu iki alanla ilgili bilgiye rastlanmamıştır.

Sonuç olarak, çalışmamızda katılımcıların "İnfertilite Stresi ile Başa Çıkma Ölçeğì" alt boyut ve toplam ölçek puanları arasındaki korelasyonlar incelendiğinde; alt boyut puanları arasında sadece "aktif mücadele etme" ve "anlam bulma temelli" alt boyut puanları arasında pozitif yönde, zayıf-orta düzeyde, istatistiksel olarak anlamlı korelasyon bulunmuştur. Tüm alt boyut puanları ile toplam ölçek puanı arasında ise pozitif yönde, istatistiksel olarak anlamlı korelasyonlar mevcuttur. Toplam ölçek puanı "pasif yok sayma" alt boyut puanı ile zayıf-orta, "aktif yok sayma" alt boyut puanı ile ortaiyi, "aktif mücadele etme" ve "anlam bulma temelli" alt boyut puanları ile ise iyi düzeyde koreledir.

$\mathrm{Bu}$ sonuçlar değerlendirildiğinde, yaptığımız çalışma bize Türkiye'de IVF tedavisi 
gören infertil kadın bireylerin stres ile başa çıkma seviyelerinin düşük olduğunu göstermiştir.

\section{KAYNAKLAR}

1. Rowe P.J, Comhaire F.H, Hargreave T.B, Mellows, Heather J \& World Health Organization. WHO manual for the standardized investigation and diagnosis of the infertile couple Cambridge University Press;1993.

2. Rowe, P.J., Comhaire, F.H., Hargreave, T.B. ve Mahmoud, A.M.A. İnfertil Erkeklerin Standart Araştırma Tanı ve Tedavileri İçin Dünya Sağlık Örgütü El Kitabı. E. Orhon (Çev.Ed.), World Health Organization. United Kingdom: Cambridge University Press;2000.

3. Kirca N. Pasinlioğlu T. Psychosocial Problems In Infertility Treatment. Psikiyatride Guncel Yaklasimlar.2013; 5(2), 162-178.

4. Adler JD, Boxley RL. The psychological reactions to infertility: sex roles and coping styles. SexRoles 1985;12:271-279

5. Clapp D. Emotional responses to infertility. Journal Of Obstetric, Gynecologic, and Neonatal Nursing (Supplement). 1985; 32s-35s.

6. Callan V. Hennessey JF. The psychological adjustment of women experiencing infertility, British Journal of Medical Psychology. 1987; 61, 13-140.

7. Cook EP. Characteristics of the biopsychosocial crisis of infertility. Journal of Counselingand Development. 1987; 65, 465-470.

8. Daniluk JC. Infertility: Intrapersonal and interpersonal impact. Fertility and Sterility.1988; 49, 982-990.

9. Domar AD. Seibel M. The emotional aspects of infertility. In M. Seibel (Ed.), Infertility: A comprehensive test. 1990; 23-25. AppletonLange.

10. Dunkel - Schetter C. Lobel M. Psychological reactions to infertility. In A. L. Stanton\& C. Dunkel-Schetter (Eds.), The Plenum series on stress and coping. Infertility: Perspectives from stress and coping research.1991; 29-57. PlenumPress.

11. Draye MA D. Lemcke J. Pattison L.A. Marshall D.S. Cowley (Eds.) Emotional Aspects of Infertility. Current Care of Women Diagnosis \& Treatment. McGraw - Hill: Lance Medical Books.2004; 572-576.

12. Türkçapar F. Vardereli K. Türkçapar $\mathrm{MH}$. İnfertilite ve Psikolojik Boyutları. İçinde M.N. Çiçek (Ed.). Temel Üreme Endokrinolojisi ve İfertilite. Ankara: Palme Yayıncılık; 2008; 339-344

13. Tarlatzis I, Tarlatzis B.C, Diakogiannis I, Bontis J, Lagos S, Gavriilidou D et al. Psychosocial impacts of infertility on Greekcouples. Human Reproduction.1993; 8, 396-401.

14. Ağargün M.Y, Beşiroğlu L, Kıran Ü.K, Özer Ö.A, Kara, H. COPE (Başa Çıkma Tutumlarını Değerlendirme Ölçeği): Psikometrik özelliklere ilişkin bir ön çalışma. Anadolu Psikiyatri Dergisi.2005;6, 221-226.

15. Peterson B.D, Newton C.R, Rosen K.H, Skaggs G.E. Gender differences in how men and women who are referred for IVF cope within fertility stress. Human Reproduction.2006;21, 2443-2449.

16. Yılmaz T. Kadın Sağlığı Ve Hastalıkları Hemşireliği Anabilim Dalı Doğum Ve Kadın Hastalıkları Hemşireliği Programı. Yüksek Lisans Tezi, İstanbul Üniversitesi, Sağl1k Bilimleri Enstitüsü, İstanbul.2012.

17. Lechner L, Bolman C, Van Dalen A. Definite involuntary childlessness: Associations between coping, social support and psychological distress. Human Reproduction.2007;22, 288-294.

18. Bayley T.M, Slade P, Lashen H. Relationships between attachment, appraisal, coping and adjustment in men and women experiencing infertility concerns. Human Reproduction.2009;24, 2827-2837.

19. Schmidt L. Infertility and assisted reproduction in Denmark. Epidemiology and psychosocial consequences. Thesis for Degree of Doctor of Medical Sciences, University of Copenhagen, Denmark. 2006.

20. Yılmaz T. Oskay Ü.Y. İnfertilite Stresi ile Başa Çıkma Yöntemleri ve Hemşirelik Yaklaşımları. Sağlık Bilimleri ve Meslekleri Dergisi. 2015; 2,100-112.

21. Lazarus S, Richard and Folkman, Susan; Stress, Appraisial and Coping, Springer Publishing Company, New York. 1984.

22. Park C.L, Folkman S. Meaning in the Context of Stressand Coping. Review of General Psychology. 1997; 30, 115-144.21.

23. Şahin HN, Durak A. Stresle başa çıkma tarzları ölçeği; üniversite öğrencileri için uyarlanması. Türk Psikoloji Dergisi 1995; 10:56-73.

24. Peterson B.D, Pirritano M, Christensen U,et al. The impact of partner coping in couples experiencing infertility Hum. Reprod. 2008;23: 1128-1137

25. Schmidt L, Christensen U, Holstein B.E. The social epidemiology of coping with infertility. Human Reproduction.2005; 20, 1044-1052.

26. Holter H, Anderheim L, Bergh C, Möller A. First IVF treatment-short-term impact on psychological well-being and the marital relationship. Hum. Reprod. 2006;21:3295-3302 